\title{
Conflict Zones of the Middle East: New Challenges in Search for Durable Solutions for the Arab Refugees
}

\author{
Misbah Saboohi \\ Senior Law Lecturer at College of Law, Prince Sultan University, Riyadh, KSA \\ Email:msaboohi@psu.edu.sa
}

How to cite this paper: Saboohi, M. (2018). Conflict Zones of the Middle East: New Challenges in Search for Durable Solutions for the Arab Refugees. Beijing Law Review, 9, 564-581.

https://doi.org/10.4236/blr.2018.94033

Received: July 8, 2018

Accepted: September 22, 2018

Published: September 25, 2018

Copyright (c) 2018 by authors and Scientific Research Publishing Inc. This work is licensed under the Creative Commons Attribution International License (CC BY 4.0).

http://creativecommons.org/licenses/by/4.0/

\section{(c) (i) Open Access}

\begin{abstract}
Conflict zones of the Middle East (Iraq, Syria) have seen a new phenomenon of hardship by their people to reach safety. Finding refuge is now a challenge which has defeated the very spirit of United Nations organization (UNO) \& its supporting agencies which were initially made to help the refugees. This article mentions the reluctance of states that United Nations High Commission for Refugees (UNHCR) is facing to give protection to refugees coming from Syria and Iraq. It means that international legal framework developed post World War II is crumbling. Refugees are no more welcomed. The legal restrictions by the receiving states introduced a new problem of human trafficking. Refugees are "criminalized" for entering the receiving states without legal papers. These helpless people are now almost stateless due to losing promised protections of International law for the victims of wars. The state-parties to the 1951 UN Convention For Refugees, have abandoned treaty duties. This article outlines the international law challenges from the states about the refugees coming from Middle East. Article gives an overview for the current state practices of the $1951 \mathrm{UN}$ convention for Refugee protection and later in the end, article offers some solutions.
\end{abstract}

\section{Keywords}

Refugees, Asylum, Human Trafficking, United Nations Organization Forcefully Displaced People, Protection

\section{Introduction}

The world has forgotten that it was actually some refugees who when allowed to reach safety in another land contributed to the world's progress. First toilet paper of UK was made by German refugees in 1945, "Fish and Chips" was intro- 
duced to Britain by Portuguese refugees and not to forget Steve Jobs for iPhone and touch-screen revolution. A refugee named Albert Einstein a distinguished physicist of the $20^{\text {th }}$ century, was an ardent advocate for "science-for-Peace-of-the-world", not destruction. It was possible because there was safety given to these refugees trying to save their life. Nearly 40 million people were forced to flee in World War II and at that moment, the states started to think of finding a durable solution to look after them. In the beginning, the purpose of refugee debate was to "save" these people and their "settlement" to safe areas. Even then, the states were skeptical of the protection right and governments did not favor this help given to the fleeing people, e.g. Soviet Union (now Russia) saw this policy by the west as an excuse to protect persons who were actually state-enemies and were wanted in their courts. As time passed by and more conflicts emerged in Eastern Europe, Asia, and Africa, a new attitude emerged. The world started to see these fleeing people as a burden (Flynn, 2002). This article is written with the perspective that the refugee crises post $9 / 11$ is now more regulated through national legislation rather than international law. There is an obvious divide between the states about the "durable solution" and assistance provided to people looking for shelter in other countries. Political considerations dominate the governments' commitments rather than post WWII spirit when the world had united to save the humanity from suppression.

The research so far done about Middle East refugees highlights the problem of respect for international law. Unfortunately, this is coming from the states which made the law for the refugees. This article will discuss the tackling of major refugees problems within frame work on international treaty of 1951 Convention for refugees. The new interpretations of the convention should be human right based which is duty of each state. The article also dissects the problem with Turkey-EU treaty of 2016 about refugee management. Refugee trafficking is a serious problem which is discussed with a view to give a version of those using the illegal routes and why are they using these criminal gangs for crossing the borders.

\section{Materials and Methods}

The article used scholarly research done in the previous ten years to analyze the data and state-practice about refugees leaving their countries. The material revealed the insensitivity of the international community to the same rules that were developed as international legal norms. Rachel Reilly (Reilly, 2001) argued that United Nations high commission for refugees (UNHCR) is now compelled to use a new term "forcibly displaced persons" because there is little difference left between internally displaced persons and those crossing international borders. Both groups need UNHCR's assistance across the globe. USA secretary of state in 2000, after his trip to Angola, proposed that now the division between internal displace people and refugees should be abolished and all assistance should be provided through UNHCR to all those displaced from their homes. 
The website of UNHCR shows the number of refugees by the end of 2016 around the world as 67.75 million and they are called "person of concern" (popstats.unhcr.org). Majority of these people leaving are from Middle East countries, especially Syrian, Libya and Iraq (Now Rohingya refugees also added to this number in 2017). Biggest number out of all these people is of refugees (25.4\%). Ms Rachel discussed the challenges of UNHCR that has made its work difficult due to insufficient funds and lack of cooperation by states on ground. Elizabeth Holzer (2013) mentioned the problems of mishandling of the refugees when they cross the borders looking for help. There is pushback policy by the states, which has multiplied the suffering of the refugees. It has given rise to refugee camp mismanagement and transnational crime gangs. Women and children are most vulnerable groups as refugees and last two years' media reports show heartbreaking images fleeing people in most dangerous conditions, even loosing lives. Burden sharing is also weak internationally. Sharon Pickering (Pickering, 2007b) examined Convention on Transnational Crimes to show the rubric of changing and broadening nature of refugee problem. Pickering shows the sad part that states now refuse any type of help to the fleeing refugees because they used illegal routes to cross border. Due to this, refugees from the Middle East are facing most painful times. Death, hunger, imprisonment seems to be the fate of Arab refugees since 2013 when the Iraq and Syrian crises got momentum. Western states failed to show respect for the international law guarantees because they see these Middle Eastern refugees as a "threat" to society and economy. The article will argue that this aspect needs to be seen in humanitarian context and not just under criminal law lens. Lack of cooperation has also jeopardized the right of asylum given in international law. The Economist (Economist Staff, 2016a) aptly discussed Turkey-EU agreement effect on refugee solution. The magazine writes that the agreement is encouraging forced return to same crises zones where these desperate people are running from.

\section{Discussion}

Michael Flynn (Flynn, 2002) argues that during cold war time these people were deported out in the name of "repatriation" policy under international law. It meant that when the war ends, such families should go back to their home countries. It did not take into account any "threats" still prevailing in those areas to these repatriated people. This caused some genuine victims in need of protection forced to leave or even turned away from borders of the $3^{\text {rd }}$ states. As time passed by, War victims were seen as people only in search for better lives. As a result, today difference in Migration and the genuine need for refuge from danger has been mixed up and seriously affected the duty by states to respect international rules for refugee protection. Now managing refugee crises has become stressful. States now do not want everyone coming to stay in their land and term them as "illegal migrants" but not a genuine refugee. In this respect, the refugees fleeing the conflict zones of Syria and Iraq are particularly suffering. The world 
attitude is now very anti-refugee and hostile. It can be seen that many new restrictive state practices have been adopted. To mention some, the United States has put up new rules for asylum seekers or that seeking refugee status. As a result Figure 1 below demonstrates how the number of refugees entering USA in 2017 has been cut after President Trump came into power. From 94,837 persons admitted into USA in 2016, they are now reduced to only 29,022 persons last year.

\section{Refugee admissions plumment: President Trump slashed the number of refugees admitted to the U.S. in 2017}

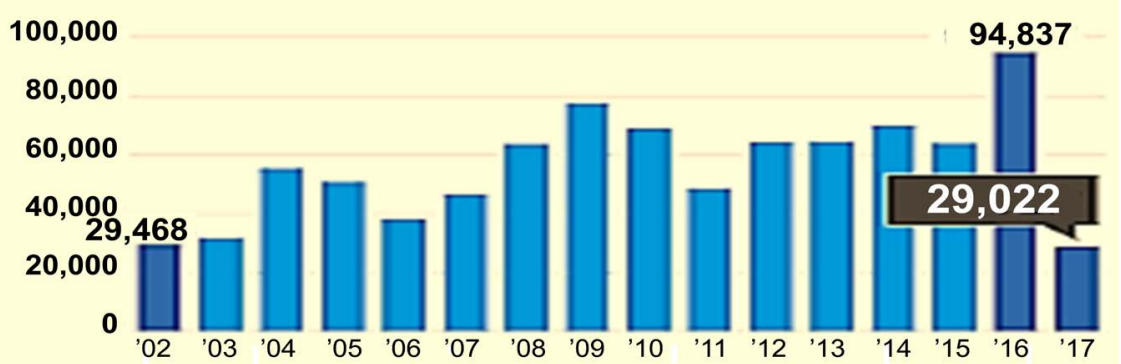

SOURCE U.S. State Department; Data from Jan. 20 to Dec. 31 of each year George Petras/USA TODAY

Figure 1. USA Statistics of refugees from 2016 to 2017. Source: (USA TODAY, 2018) Source: (Alan Gomez report in USA TODAY, January; 2018;

https://www.usatoday.com/story/news/world/2018/01/03/refugee-admissions-u-s-plumm et-2017/999903001

EU has seen a surge in nationalistic movements become very popular in their recent elections in some countries (France, Greece, Norway). The United Kingdom has brought rigorous checks for migrants in the name of Brexit and Australia already has a strong anti-asylum political party against foreigners.

With all this taking place, this article aims to search what are the most stringent practices by states that are adding to misery of plight of refugees leaving the Middle East region and how to give protection to these refugees in the new world order where the balance of power is in favor of donor states who do not welcome these refugees. The article seeks to explore questions like is there a new definition of a refugee now and who are now accepted for protection? The article shall show the hostility of developed states towards Refugees form Middle East in particular and reasons behind it. In the end, there will be some recommendations given for better safety for the victims of wars crossing borders.

\section{United Nations Convention on Status of Refugees (Adopted in UN General Assembly, 1950)}

In October 2000, United Nations High Commission for Refugees (UNHCR) started a review process after 50 years of its establishment (United Nations High Commissioner for Refugees, 2000). The purpose of this review was to evaluate 
nature of conflicts and violations of human rights which cause forced displacement and fleeing of people to other states. It also aimed to see the commitment of the states to the 1951 United Nations Convention on Status of Refugees for refugee protection. The study also searched for more practical solutions for the refugees because many states showed reluctance of their commitment to the UN Convention. For this, it was necessary to find out exact figures of people looking for help around the world. As a result of continued surveys currently indicate that there are total of 67.75 million people looking for sustainable safety for themselves (United Nations High Commissioner for Refugees, 2018b). The available statistics on UNHCR website, as shown in Table 1, mention the statistics and percentages of "persons of concern" looking for shelter worldwide.

Table 1. Various groups of people displaced.

\begin{tabular}{ccc}
\hline Category & Total number & Percentage \\
\hline Refugees & $17,187,488$ & $25.4 \%$ \\
Asylum seekers & $2,826,508$ & $4.2 \%$ \\
Internally displaced persons & $36,627,127$ & $54.1 \%$ \\
Stateless persons & $3,242,207$ & $4.8 \%$ \\
Returnees & $7,063,374$ & $10.4 \%$ \\
Others & 803,134 & $1.2 \%$ \\
\hline
\end{tabular}

Source: Population statistics (http://www.unhcr.org/ March 2018).

The results of the study conducted by UNHCR also indicated that International support in not enough and host states depend only on discretionary funds. This critique gathers weight when we look at the numbers of people shown in Table 2, living as refugees in the refugee-hosting countries.

Table 2. Refugee numbers in different states.

\begin{tabular}{cc}
\hline Host Country & Number of refugees \\
\hline Jordan & 664,118 \\
Turkey & $2,869,421$ \\
Pakistan & $1,561,162$ \\
Lebanon & $1,070,854$ \\
Iran & 979,400 \\
Ethiopia & 791,600 \\
Kenya & 451,099 \\
Uganda & 940,200 \\
DR Congo & 383,095 \\
Chad & 369,500 \\
\hline
\end{tabular}

Source: http://www.unhcr.org/ March 2018.

It is clear from the Table 2 that mostly the poor/developing states with just $2.5 \%$ of the world economy are receiving the refugees. Whereas rich or devel- 
oped countries prefer only to give only financial aidto these states and leave them to look after the most vulnerable people on earth (e.g. The United Kingdom took only 8000 Syrian refugees since the war of 2011 and Jordan took 655,000 same years). Figure 2 shows alarming pattern of distribution of refugees worldwide. Turkey, Lebanon and Pakistan which are economically challenged states, have the largest number of refugees living inside their borders whereas Europe has the small number of $17 \%$ and America hosts only $16 \%$.

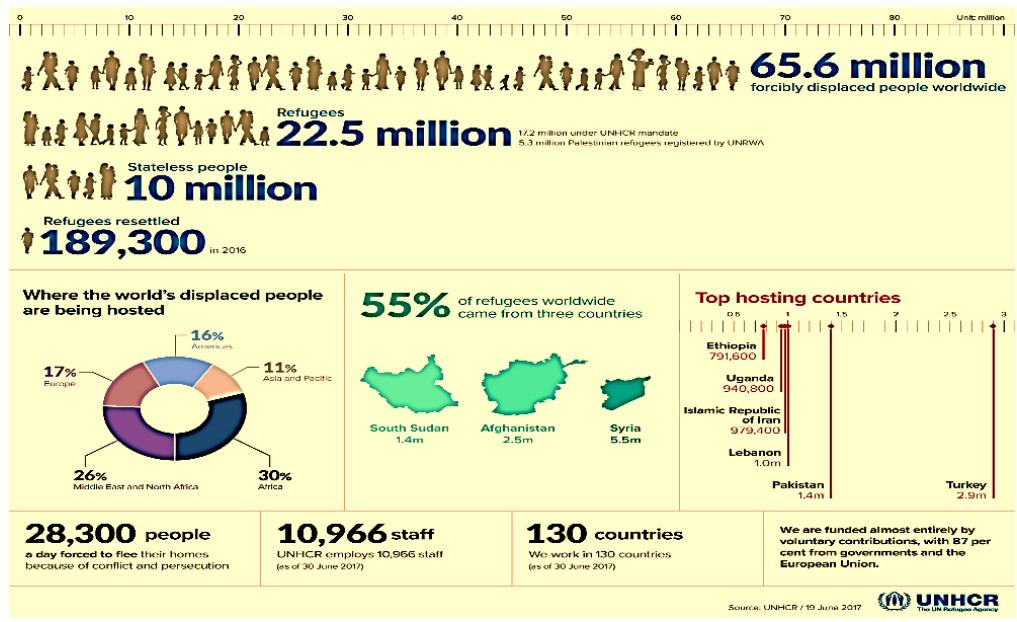

Figure 2. Chart of the Host states for refugees. Source: (http://www.unhcr.org/; March 2018. Figures at a glance)

However within months the new data of UNHCR in Figure 3 shows increase in the number of refugees from 65.6 million to 68.5 million, and but the hosting states remain the same. Data shows that $85 \%$ of displaced people are still from developing states. Number of refugees also increased from 22.5 million to 24.4 million. Figure 3 should raise our concerns as advocates of international law safeguards for the people in need of shelter.

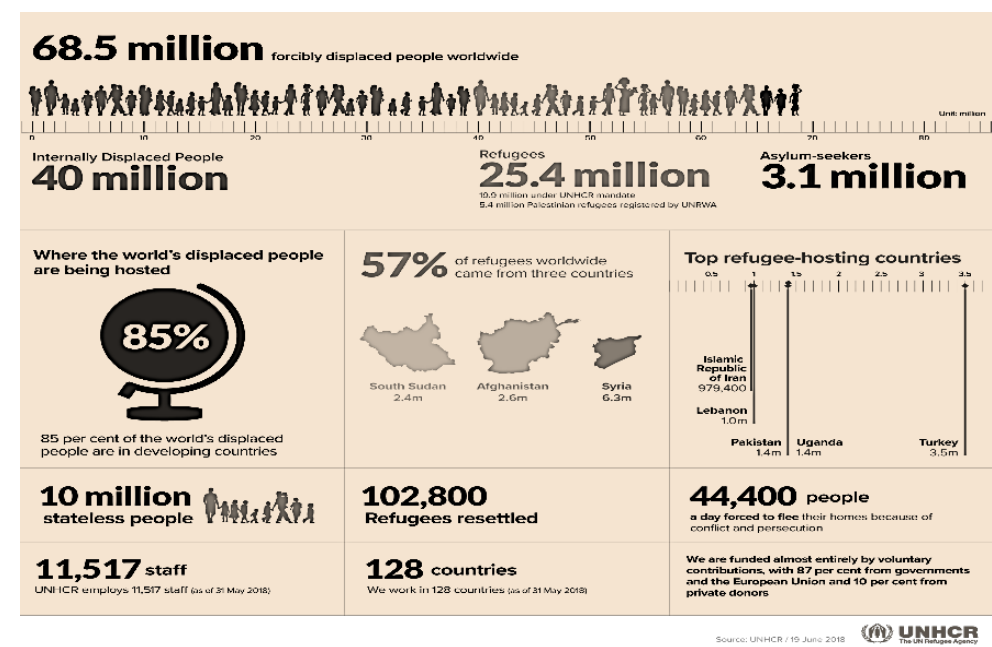

Figure 3. Sharp increase in number of refugees. Source: Source: (http://www.unhcr.org/; June 2018. Figures at a glance) 
The spirit of 1951 UN Convention was to find solutions to the problem of refugees (United Nations High Commissioner for Refugees, 1951ab). But the international commitment to solving refugee problems has been luke-warm since many years (Hathaway \& Neve, 1997). In 1990s the annual budget of UNHCR was US $\$ 1$ billion and now UNHCR needs US $\$ 7.7$ billion annually (United Nations High Commissioner for Refugees, 2018b). Hathaway \& Neve (1997) criticizes how the developed countries have failed to provide a durable help and solution to the refugees around the world. He regrets the lack of solidarity and cooperation of international community, lack of funding for Refugee agency. The current states hosting and taking care of refugees are actually those which are developing economies and cannot support a large number of refugees from their own resources.

It is pertinent to note that, the definition of "refugee" also has attained new meanings. Initially, a refugee was any one who fulfilled definition of 1951 UN Convention (Hathaway \& Neve, 1997). The definition as given in article 1.2 of the 1951 Convention is:

"As a result of events occurring before 1 January 1951, and owing to well-founded fear of being persecuted for reasons of race, religion, nationality or political opinion, is outside the country of his nationality and is unable or, owing to such fear or for reasons other than personal convenience, is unwilling to avail himself of the protection of that country; or who, not having a nationality and being outside the country of his former habitual residence, is unable or, owing to such fear or for reasons other than personal convenience, is unwilling to return to it."

But now many new categories have been added to UN agency for refugees' protection mandate. Table 3 will show how the legal regimes and terms are changing and emerging to expand the scope of protection by UNHCR.

Table 3. New Categories of persons in need of UNHCR shelter.

\begin{tabular}{|c|c|}
\hline Category & Definition \\
\hline Humanitarian Crises & $\begin{array}{l}\text { African continent war conflicts } \\
\text { people with special or temporary protections } \\
\text { people in a refugee-like situation }\end{array}$ \\
\hline Asylum seekers & $\begin{array}{l}\text { The group whose refugee status is not yet determined and they seek interna- } \\
\text { tional protection under human rights law. }\end{array}$ \\
\hline IDPs & $\begin{array}{l}\text { People who have been forced to leave their habitual residence in their coun- } \\
\text { try due to war like the situation or human right abuses .they have not } \\
\text { crossed international borders. }\end{array}$ \\
\hline Stateless people & $\begin{array}{l}\text { People who do not possess the nationality of any state by law or their natio- } \\
\text { nality is yet to be determined }\end{array}$ \\
\hline Others & The group which needs humanitarian aid or other protection by UNHCR. \\
\hline
\end{tabular}

For this reason, UNHCR no more uses term refugee. It now terms these people as "forcibly displaced people".

Another angle from which the refugee influx can be examined is the areas, 
which are producing these refugee or IDP groups.

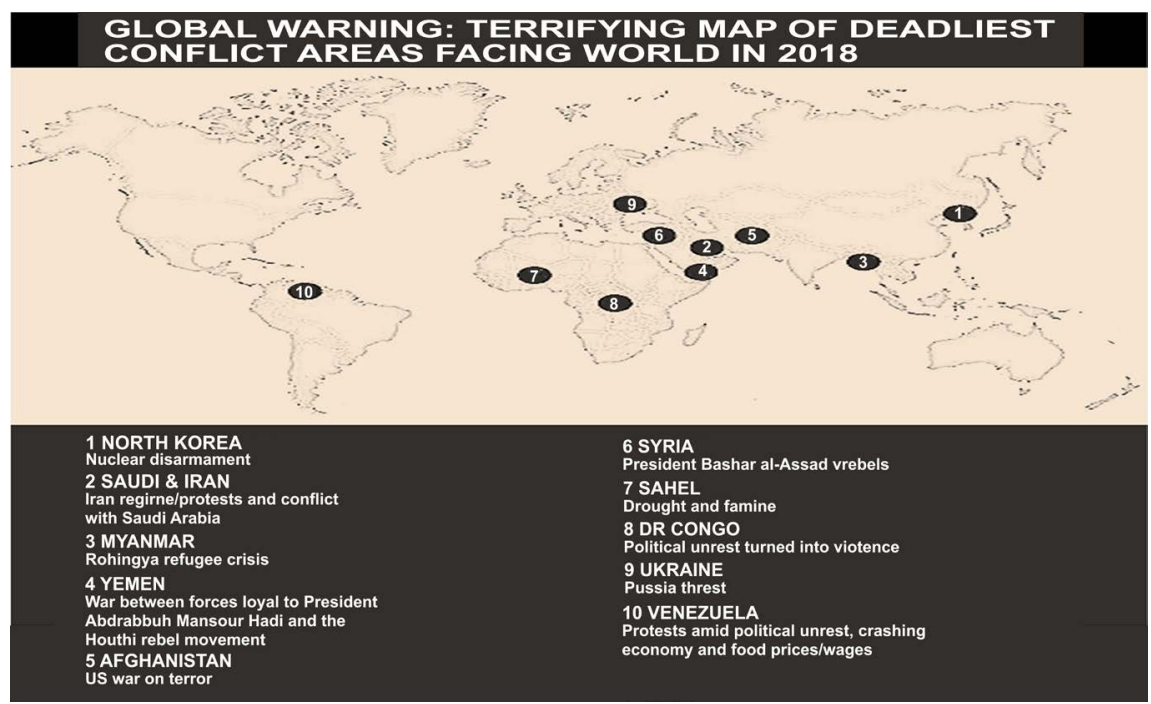

Figure 4. World map of areas producing refugees. Source: (http://www.unhcr.org/; image 2018)

The Figure 4 has the following indicators for us to pay attention to:

1) Muslim countries of Africa and MENA region are the largest producers of the refugees and internally displaced people (Syria, Iraq Somalia, Ethiopia, Nigeria, Yemen, Afghanistan, South Sudan) Syrians continued to be the largest forcibly displaced population, with 12 million people at the end of 2016. Colombians were the second-largest group, followed by Afghans. Other large displaced populations at the end of 2016 included Iraq and South Sudan.

2) $55 \%$ of all refugees worldwide came from just three countries: Syrian Arab Republic (5.5 million) Afghanistan (2.5 million) South Sudan (1.4 million)

3) Europe/South America states (Ukraine, Burundi, Central African Republic, Colombia and Guatemala) have less number of refugees and IDPs from their conflicts.

4) Western states (Germany, France UK, Sweden, Canada) are the preferred destination by refugees from the Muslim states and this is even forcing them to take dangerous sea routes and be exploited by the human smugglers.

From the data of UNHCR, the challenges that now emerge in international state-practices for providing durable protection to the displaced people (or refugee groups) are numerous. Foremost is the lack of support for the 1951 Convention on status of refugees by the host states. Many EU states now criticize the convention as being outdated and against national interests of these countries. As a result domestic procedural obstacles have been created by these states for granting asylum status to a refugee and we find more stateless people. In fact now Internally Displaced Persons (IDPS) are more in focus for assistance than the refugees because IDP status prevents people from crossing international borders. Today IDPs protection is evolving which is making governments to 
re-look into their role as the host country for the international refugees. Flynn (2002) mentions that terms of refugees, asylum seekers and IDPs have been distributed in different international treaties \& regimes to select and help them. Therefore states reject many applicants of protection on the pretext of non-application of treaty obligation because the category the applicant falls into is not in the treaty they use. Hence, the problem of refugee in search for protection is multiplied.

The states are also interpreting the 1951 UN Refugee Convention very narrowly in order to ignore their obligations under it. UNHCR was created in 1950 to look for lasting \& durable solutions for the refugee crises after WWII. In fact the 1951 Refugee Convention grants all refugees equal access to important state institutions including housing, courts, public welfare, schools, labor market etc.

Article 16:

1) A refugee shall have free access to the courts of law on the territory of all Contracting States.

2) A refugee shall enjoy in the Contracting State in which he has his habitual residence the same treatment as a national in matters pertaining to access to the Courts, including legal assistance and exemption from cautio judicatum solvi.

Article 21:

As regards housing, the Contracting States, in so far as the matter is regulated by laws or regulations or is subject to the control of public authorities, shall accord to refugees lawfully staying in their territory treatment as favourable as possible and, in any event, not less favourable than that accorded to aliens generally in the same circumstances.

Article 23

The Contracting States shall accord to refugees lawfully staying in their territory the same treatment with respect to public relief and assistance as is accorded to their nationals.

1951 Convention On The Status Of Refugeealso prohibits host states from deporting refugees to the country from which they fled (non-refoulement).The convention prohibits expulsion of any refugee on its territory to a place where his life is in danger owing to his race, religion, nationality, membership of particular social group or political opinion. ${ }^{1}$ To implement UN system for refugees, it includes the other international agencies like the World Food Program, International Organization for Migration, non-government organizations (e.g. Oxfam). 50 million people have been assisted through this in last 5 decades (Flynn, 2002). However, these organizations have no enforcement method or powers, they can only support UNHCR. The UNHCR tries its best to compensate the state services, migration programs, or infrastructure in their refugee camps (Kagan, 2006; Slaughter \& Crisp, 2008). However, the sad fact is that today not all refugees are equal. In 1951 European crises of WWII was the reason for adopting the UN Refugee convention and the rights created in that treaty were made

${ }^{1}$ Article 33 of the 1951 convention on the status of refugees. 
for those people in that particular time of history. Now the same treaty is seen as too flexible for the current times and too easy for the new cadre of refugees who are fleeing from Middle East and Africa (Syria, Libya, Iraq), not Europe. It shows the bias of the western governments against the people fleeing from Asia or Africa. To take one example, France and Germany do not accept refugees from states like Algeria because they interpret the 1951 convention that such people can seek refuge within their own state since it is not the state that is persecuting them but non-state actors (Reilly, 2001). Some countries refused asylum protection to Siri Lankan civil war victims calling it the "internal" matter for Siri Lankan government.

To add insult to injury, alternative new local remedies have been "invented" by the developed states ignoring international obligations by the host/receiving states which gives less or limited protection only (e.g. Many states are legislating their own domestic refugee laws and creating different definitions of "refugee" that leads to rejection of genuine asylum applications). Such variety of definitions lead to rejection of genuine asylum applications. Hostility towards refugees is not just limited to Europe. Now it is a general trend that Middle East refugees are looked as security risk and burden on the economy. Many locals target these refugees for hate crimes. Human Rights Watch reports decline of interest by states to give protections to the Asian or African refugees. E.g. Guinea has largest refugees from Sierra Leone and Liberia, butanti-refugee sentiment led to attacks against refugees, including gang rapes of women, in the year 2000. Even the head of UNHCR was murdered by the attackers at Liberian borders by the local population attackers (Reilly, 2001).

UNHCR is also facing cutting down on its financial contributions from member countries. At the moment more than 142 states are signatory to the convention but Burden sharing responsibility is very unequally shared (Suhrke, \& Newland, 2001). Today there are shortcomings in "burden-sharing" between the developed and developing states, which are effecting refugee protection (Betts, 2003). To see how it affects UNHCR operations we have example of African refugees in 1999 when it could not raise enough funds for refugees of Guinea and Sierra Leon and the refugees were exposed to serious risks at borders. There was only US $\$ 35$ per person, which shows how difficult is to get donations from the donors now. Even those states that are party to the refugee convention do not always offer refugees their duly enforceable rights. These global changes and unequal regimes have become almost institutionalized which have practically left refugees few legal choices and bleak hope of respectable life.

Most policies in the developed states aim to contain the humanitarian crisis to neighboring countries and to stop refugees from reaching their borders (Aleinikoff, 1995). The developing countries also resist the entry refugees in order to save their local economic resources for their own people. All this is going on at the expense of refugees (Aukot, 2003). This has increased the tensions and the tug of rules between the international communities, which encourage exclusionary policies in the refugee camps themselves. 
If the refugee camps are set up then the Camp administration too does not generally treat people living in refugee camps as "deserving" adults in unfortunate circumstances, rather they are treated as un-informed and potentially hostile people who use falsehood to gain access to resettlement, food, and other forms of humanitarian aid (Agier, 2011). Let us examine the Turkey \& EU arrangement for control of refugees from Syria and situation created in their refugee camps. The EU-Turkey treaty was signed in March 2016 as "Readmission Agreement". It practically limited the right of Syrian and Iraqi refugees to apply for asylum in the Greece border and they are all to be compulsorily returned to Turkey and stay in a camp until their legal papers are prepared. ${ }^{2}$ Each Syrian refugee returned to Turkey will be allowed to enter EU under a "resettlement scheme" when application is processed properly. ${ }^{3}$ Turkey has agreed to set up processing centers at borders with Syria for the screening process of those trying to cross Greek border. EU is of the view that it helps process application properly without chaos and will prevent smugglers from minting money from the needy refugees or refugees themselves taking risky routes. In return, EU has pledged \$3.3 billion payment to Turkey to help stop fleeing groups entering EU from unconventional routes (Economist Staff, 2016a). ${ }^{4}$ Egypt Foreign minister called the treaty as "migrants swapping" (BBC, 2016) $)^{5}$ because treaty actually allows one Syrian refugees to be given asylum in Greece in return for one irregular migrant sent back to Turkey. UNHCR gave its cautious reaction on the treaty that refugees need protection from persecution, not rejection (United Nations High Commissioner for Refugees, 2016). The treaty should not encourage refoulement of those in need of protections (United Nations High Commissioner for Refugees, 2016). As a result of this treaty, the desperate families trying to reach European shores of Spain or Greece are still using Mediterranean and Aegean Sea routes. These are now the most dangerous routes for reaching safe lands by the fleeing refugees. It means the treaty has actually halted the ease for refugees and it has delayed the safety outreach for the refugees. It actually encourages the return of any refugee from EU borders who take illegal routes to enter EU states. The return is without any safeguards or protection-guarantees for the returnees. The agreement leaves the question unanswered that who will enter EU and who won't? It is decided only on discretionary basis by an officer at the border deciding the applications. Only those coming from Europe will be granted refugee status at Turkey centers. What about those directly coming from Syria or Iraq or

${ }^{2}$ Now any refugees from Middle East crossing the Aegean Sea will be automatically sent back to Turkey where they will join the line for asylum seeking applicants in camps set up at turkey borders.

${ }^{3}$ The terms include the speeding up of a $\$ 3.3$ billion payment pledged to Turkey in October 2016, the sum eventually will be doubled to help pay for improved conditions in Turkey's refugee camps over the next 3 years. Turkey wants in return the opening of five new "chapters" in long-stalled discussions about Turkey's aim to become an EU member and the relaxation of visa requirements for Turkish citizens entering the EU.

${ }^{4}$ According to International Migration Organization every year almost 300 migrants taking sea boats still die by drowning including small children.

${ }^{5} \mathrm{BBC}$ (2016) Monitoring Middle East, Mar 23, 2016 .available at

https://explore.proquest.com/document/1775210578 
other countries? They shall all be deported to dangerous war zones.

The EU-Turkey arrangement has actually made family unions more difficult because time for processing is long and it increased anxiousness of applicants to leave the refugee camps by illegal means. Due to technical legal innovations of this agreement, now refugees also need lawyers to help them in their cases which itself is a time-consuming process. Many are kept in camps cum detention center for years until their applications are processed. Filippo Grandi, the Head of the UN Refugee Agency, told the European Parliament that he was:

"Deeply concerned about any arrangement that would involve the blanket return of anyone from one country to another without spelling out the refugee protection safeguards under international law."

As a result, many Syrian and Iraqi people are being deported arbitrarily from Greece which has created a refugee night mare at Turkey border (Not to forget that it has not discouraged the refugees from still taking risky sea journeys to reach safety). It has now militarized Aegean Sea in order to stop refugee boats since February 2016.

Such "Push-back" attitude of Europe has helped in emergence of a new challenge; transnational crime. Many states feel that foreigners entering the new state pose a threat to the state and local people. It is now seen as a national threat. Rich states look at refugees as outsiders, their arrival is looked unfavorably and illegal (Pickering, 2007a). Due to this attitude of rich states, refugees somehow end up as unwelcomed groups. The reasons are forgotten why these were forced to flee their states. Such narrative connects the refugees to illegal traffickers, which are ready to give help to them to flee their countries. Organized crime rings are no doubt taking advantage of it. But border Officials only look at how the journey was accomplished, instead of the reason, if it is illegal they reject their status immediately. So it is already a police case when a helpless person arrives on shores. Human traffickers are making a party from these unfortunate policies of the European countries. In order to defeat the delaying systems of EU, migrants are pressed to use the illegal channels, which promise to put them inside EU borders circumventing legal routes because the suffering is huge, and escape is the urgent choice. Refugees are using smuggling syndicates to reach safety. Women and children are especially at risk from such smugglers who also send female refugees into slavery or sex business. The conditions under which the traffickers transport the refugees are also shocking. ${ }^{6}$ It is not helping when states are legislating more curbs on border crossing. The state should see why people are forced to use such means to travel (Reilly, 2001).

The criminal groups are exploiting the vulnerability of the families running for safety. One research suggests that any refugee now has to somehow seek smuggler's help at some point in his struggle (Koser \& Pinkerton, 2002). In this sense, the refugees are considered partners in crime, involved in a commercial transaction (Gallagher, 2002). States feel that refugees had a choice of choosing the mode of traveling and they chose the unlawful method and had money to ${ }^{6}$ Many died of suffocation in airtight containers of trucks, many drowned in sea in plastic boats, and many have been left in roadsides and jungles to fend for themselves. 
spend too. It is double criminality (Feller, 2001). Rich states also blame the refugees for bad choices and punish them for it by having many barriers to refugee entries (Weber, 2006). Protecting national border is now a primary international concern but not helping the needy.

UN Convention against Transnational Organized Crime 2000 (UNOTC) (United Nations General Assembly, 2000) and its 2004 Protocol against smuggling of migrants by Land, Sea an Air have now practically replaced the 1951 Refugee Convention. This is not helpful. These new treaties assume that refugees somehow behave voluntarily against the law for quick solutions and as a result, the states have made border controls stricter nowadays. These countries do not realize the desperation of the people trying to save their families. Such outlook has really defeated asylum right of the refugees. First, a refugee will not be able to reach the safe place and if he does, the laws will criminalize him. Strict laws encourage illegality too. When opportunity decreases for safe passage then demand for criminal gangs increases.

Majority of the refugee population is now placed in camps, which are hastily developed and located in very poor regions. They have become "failure image" of international law. It is evident from Calais and German refugee centers' reports that refugees are left in a limbo and endless waiting for legal relief. How can these people living an uncertain life really care about legal delicacies? (Holzer, 2013). Holzer has concluded after observing human right violations in refugee camps that the existing legal instruments offer little security or justice for people living in refugee camps.

The most important legal guarantee under the $1951 \mathrm{UN}$ refugee convention was that the refugee should not be forcibly returning to the country of origin where he faces persecution, (principle of Non-refoulment). Unfortunately, it is now fast changing. Host states no longer want a settlement, but repatriation (Flynn, 2002). In the years of 1950-60s the number of refugees was small and manageable. However, conflicts of the 1990s and now the Arab spring have increased the number of people looking for safety by leaps and host states do not want to take in such large population that has created issues at home. Refugee frauds also happening amidst all this because many also fled socio-economic or political causes, which are not acceptable in the legal definition. UNHCR has only "aid" programs for these refugees, but no durable solution of peaceful living is possible without states' help. Unfortunately, states are not happy anymore with the incoming foreigners (Lubbers, 2002). Media is also projecting crimes by the refugees or asylum seekers, which has increased fear of the 'others' amongst local people of host states. Refugee-phobia is on the rise. Refugees from Africa and Middle East are now blamed for the social ills in a society of the West and people want strict controls about the immigration. ${ }^{7}$ Law enforcement agencies and border-police have also been effected by the pressure from the media and the society (Lubbers, 2002). Hostility led to violence also and the result is that

${ }^{7}$ President Trump imposed travel ban in 2017 only on 6 Muslim majority states from Middle east and Africa. 
almost all states now have "push-back" policy at their borders. Asylum is now granted on quotas, which also increases the shortage of willing states ready to receive the refugees (Pickering, 2007a). The policy of "pick and choose" through quota system of refugee has added a new problem. In fact there are no fair quota allocation rules for taking in refugees. It is just decided politically by the governments. Going back is also difficult for these refugees because the war situation has not changed at all and uncertainty of everything remains (Pickering, 2007b). Resettlement program of UNHCR can only settle 160,000 spaces. There is a need for increased places, more quota numbers and more states should participate in this by offering spaces in their land. Waiting indefinitely in refugee center will only make matters worse. Many will try to break the laws to enter other states. Countries have legal and moral duty to give sanctuary to these people (Economist Staff, 2016b).

Asylum right is an important aspect in refugee protection under international law and no doubt, it was misused in the past. ${ }^{8}$ Economic migrants do not have international asylum right. The easier means of modern travel and communications also played a role to assist the people leaving their countries. But those fleeing due to human right abuses by the governments have the actual asylum right. European states now perceive even the asylum seekers as a burden and they blame the refugees to actually abuse their system. Rather than improving protection standards for the refugees European host states have decreased number of asylum applications (Reilly, 2001). The new policies have made it very difficult to get asylum, e.g.:

1) Visa requirements

2) Long list of documents needed by these fleeing refugees have made the asylum seeking almost impossible.

3) Many are penalized as illegals because they came through irregular means of travel. This also affects the decision to grant asylum.

4) There are now detention centers for the refugees to deter the others. The centers have jail like atmosphere.

5) The developed countries have adopted a new practice to settle the refugees in "Safe $3^{\text {rd }}$ state". The "Safe $3^{\text {rd }}$ countries" keep the refugees on constant deportations and no fair process is available for determination of their status, e.g. in 2015 group exclusion of Syrian and Iraqi refugees was a high-risk refoulement.

6) Sometimes the government sends them back to the countries from where the refugees entered and ask them to wait until their asylum claim is processed.

All this violates the principle of "Non-refoulement" of the refugee convention. No individual can be returned to the state where life or freedom is threatened (Reilly, 2001).

\section{Conclusion}

In such difficult times, the need is to settle the dust and again pays attention to international law state obligations in order to bring some relief to the refugee ${ }^{8}$ For example the asylum seekers increased in the 1990 s due to mainly poverty. 
crises coming from the Middle East. It is not enough to promise them protection from bombings, the refugees need durable solutions. What is needed is a "goal-oriented" international governance structure for enforcement of International laws. Some recommendations are offered here:

1) UNO must get a fresh start and it must remind its members to recognize/implement the 1951 Convention and its 1967 Protocol because it is the corner-stone of the international protection for refugees. UNO should stress on the full and effective implementation of these instruments.

2) It cannot be ignored that the best way to avoid refugee crises would be to address the "causes" of refugee creation from the Middle East and implement "preventive" strategies between states to settle their conflicts peacefully. Arab wars and Conflicts must be resolved or at least cease-fire has to be achieved to stop heavy flow of populations. Iraq, Syria, Yemen are bleeding patches on face of the earth these days and no one can deny that innocent victims are being made into refugees. They need help. There is a serious need by the rich West to show solidarity with the international community to help each other in dispute resolution plus supporting each other to help the "helpless" within their territories. Partly this can be done by devising a strategy to handle refugee issues within international and regional basis with long-lasting solutions.

3) The states must be reminded that the refugee-problems are social and humanitarian problems and it should not be a cause of tension between them. If the host-states are suffering from "host-fatigue" then these states can help in the voluntary but safe repatriation of refugees by negotiating terms of return with the home states. This will prevent refugees from remaining in degrading conditions in camps or from being exploited by criminal networks if they try to find safety.

4) Furthermore international community should not forget that economic migration and the smuggling of migrants is not new. Attempts by "would-be migrants" to use illegal channels for entry, in the absence of migration programs, should not invalidate the asylum process. While trying to control illegal entries, it is to be realized by the states that when a person is in danger and his primary struggle is to protect the family, he will not think of legal means. Border police at entry check posts can take a humanitarian attitude for this human behavior. It is a fact that many displaced people get smugglers help but it is only in desperation and these people cannot be expected to leave the country in a normal/regular method and have legal papers with them. Such people, therefore, should not be penalized at borders by refusal for stay or refusal for protection. Expelling such families will put them back into danger they tried to avoid in the first place and this decision should be taken after examining all circumstances of such applicants for asylum. Using smugglers or traffickers should not lose these people the right to get refugee status (actually, it should confirm their desperation). Given the potentially serious consequences of expelling a refugee, such an action should only be taken in exceptional circumstances, for example if presence of a person or group will directly affect national security or public order of that host 
country (Lubbers, 2002).

5) Only putting the people in refugee camps is also a not durable solution. "Order-on-the-border" approach is important. A system is needed for border checks for curbing "push-factor" by the border police. There can be bigger, better models of centers for screenings of applicants at the Middle Eastern states before people leave these states. There can be hot-spots set up by UNHCR at Italy and Greece borders close to Turkey where refugees first arrive. The refugees should be registered close their home countries. It will save them from traffickers. When applications will be processed faster and genuine refugees will be helped in these centers, the number of refugees will definitely come down.

6) Not to forget that the cost of managing the displaced people should be shared by all. The states hosting "hot-spot" centers on their land can be compensated by others. Burden sharing is important. Funding is needed for strengthening the camps and their security.

7) Another serious issue is the capacity of the teams working in the refugee camps on applications for asylum status. Of course, refugees also need to show some discipline and patience for their papers to be made before they jump trains to another country but undue delays are causing more desperation in camps.

8) Camp life facilities need to be improved a lot. There is no work or schooling in the camps. The people there do not know when they can go home or given asylum, therefore they need to be given some opportunities to find work and education (United Nations High Commissioner for Refugees 1951b, 1951c, 1951d, 1951e). They can be valuable citizens later (for 4 years those admitted in Jordan, Turkey, and Lebanon were not allowed any work. They were only living a depressing camp life).

9) Last but not the least is to rekindle faith in UNHCR. It has been abandoned by states as only a processing center. UNHCR has to be more visible on international scenario for resolving refugee protection issues. It must be more out spoken against the governments which are causing displacement of people from their homes (Reilly, 2001). The zones where UNHCR has heavier presence (e.g. Middle East) its mode of working can be improved by:

a) More easier, safer access to its offices.

b) Consistent procedures

c) Use of local languages to expedite the status-determination process

d) Transparency in application processes and help remove objections to applications, appeals

It is not impossible that UNHCR can expand its role from mere humanitarian agency to a robust organization actively involved in crises settlement also by persuading states to adopt cease-fire.

\section{Acknowledgements}

The article is inspired by the International Law Track course offered by the Prince Sultan University. 


\section{Conflict of Interest}

There is no conflict of interest.

\section{References}

Agier, M. (2011). Managing the Undesirables: Refugee Camps and Humanitarian Government. Cambridge: Polity Press.

Aleinikoff, T. A. (1995). State-Centered Refugee Law: From Resettlement to Containment. In E. V. Daniel, J. C. Knudsen, J. Knudsen, \& L. Jayawardena, Mistrusting Refugees (pp. 257-272), Berkeley and Los Angeles: University of California Press.

Aukot, E. (2003). It Is Better to Be a Refugee than a Turkana in Kakuma: Revisiting the Relationship between Hosts and Refugees in Kenya. Refuge 21, 73-83.

BBC (2016). Monitoring Middle East. London: BBC. https://explore.proquest.com/document/1775210578

Betts, A. (2003). Public Goods Theory and the Provision of Refugee Protection: The Role of the Joint-Product Model in Burden-Sharing Theory. Journal of Refugee Studies, 16, 274-296. https://doi.org/10.1093/jrs/16.3.274

Economist Staff (2016a). Desperate Times, Desperate Measures; Europe’s Migrant Crisis. The Economist. https://www.economist.com/europe/2016/03/12/desperate-times-desperate-measures

Economist Staff (2016b). How to Manage the Migrant Crisis; A Plan for Europe's Refugees. The Economist. https://www.economist.com/leaders/2016/02/06/how-to-manage-the-migrant-crisis

Feller, E. (2001). The Convention at 50: The Way Ahead for Refugee Protection. Forced Migration Review, 10, 6-9.

Flynn, M. (2002). Searching for Safe Haven. Bulletin of the Atomic Scientists, 58, 22-25. https://doi.org/10.1080/00963402.2002.11460619

Gallagher, A. (2002). Trafficking, Smuggling and Human Rights: Tricks and Treaties. Forced Migration Review, 12, 8-36.

Hathaway, J. C., \& Neve, R. A. (1997). Making International Refugee Law Relevant Again: A Proposal for Collectivized and Solution-Oriented Protection. Harvard Human Rights Journal, 10, 115.

Holzer, E. (2013). What Happens to Law in a Refugee Camp? Law \& Society Review, 47, 837-872. https://doi.org/10.1111/lasr.12041

Kagan, M. (2006). Frontier Justice: Legal Aid and UNHCR Refugee Status Determination in Egypt. Journal of Refugee Studies, 19, 45-68. https://doi.org/10.1093/jrs/fej002

Koser, K., \& Pinkerton, C. (2002). The Social Networks of Asylum Seekers and the Dissemination of Information about Countries of Asylum. London: Research Development and Statistical Unit of Home Office.

Lubbers, R. (2002). Asylum for All. Harvard International Review, 24, 60.

Pickering, S. (2007a). Globalization of Violence against Refugees. London: Routledge.

Pickering, S. (2007b). Transnational Crime and Refugee Protection. Social Justice, 34, 47-61.

Reilly, R. (2001). UNHCR at 50: What Future for Refugee Protection. Migration World Magazine, 29, 13-18.

Slaughter, A., \& Crisp, J. (2008). A Surrogate State? The Role of UNHR in Protracted 
Refugee Situations. Geneva: UNHCR, Policy Development and Evaluation Service.

Suhrke, A. and Newland, K. (2001). UNHCR: Uphill into Future the International Migration Review. Geneva: UNHCR.

UN General Assembly (1950). UN Resolution: Draft Convention Relating to the Status of Refugees. http://www.unhcr.org/refworld/docid/3b00f08a27.html

United Nations General Assembly (2000). UN Resolution No. 55/25: United Nations Convention against Transnational Organized Crime. Geneva: United Nations. https://www.unodc.org/pdf/crime/a_res_55/res5525e.pdf

United Nations High Commissioner for Refugees (1951a). Article 1: Definition of the Term “Refugee” Section 2. 1951 UN Convention. Geneva: United Nations.

United Nations High Commissioner for Refugees (1951b). Article 16: Access to Courts. 1951 Convention Relating to the Status of Refugees. Geneva: United Nations.

United Nations High Commissioner for Refugees (1951c). Article 21: Housing. The 1951 Convention Relating to the Status of Refugees. Geneva: United Nations.

United Nations High Commissioner for Refugees (1951d). Article 22: Public Education. The 1951 Convention Relating to the Status of Refugees. Geneva: United Nations.

United Nations High Commissioner for Refugees (1951e). Article 23: Public Relief. The 1951 Convention Relating to the Status of Refugees. Geneva: United Nations.

United Nations High Commissioner for Refugees (2000). The State of the World's Refugees. Oxford: Oxford University Press.

United Nations High Commissioner for Refugees (2016). UNCHR on EU-Turkey Deal: Asylum Safeguards Must Prevail in Implementation. http://www.unhcr.org/en-us/news/press/2016/3/56ec533e9/unhcr-eu-turkey-deal-asylu m-safeguards-must-prevail-implementation.html

Weber, L. (2006). The Shifting Frontiers of Migration Control. In S. Pickering, \& L. Weber (Eds.), Borders, Mobility and Technologies of Control (pp. 21-43). Dordrecht:

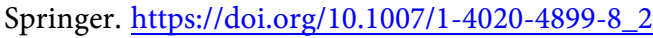

\section{Data Availability Statement}

https://explore.proquest.com/document/1470424861

https://explore.proquest.com/document/212028034

https://explore.proquest.com/document/231911977

https://explore.proquest.com/document/197842679

https://explore.proquest.com/document/1762752798

https://explore.proquest.com/document/1772404066

https://explore.proquest.com/document/230881208 